\title{
WRITERS, INTELLECTUALS, POLITICS: THE TRANSFORMATION OF THE CULTURAL FIELD IN POST-COMMUNIST ROMANIA
}

\author{
MARIUS LAZĂR 1
}

\begin{abstract}
The article aims to illustrate the mutual dependencies and transfers between different segments of the cultural field and areas of civic or political activities, together with the function these changes fulfil in redrawing individual trajectories and then the balance of forces. The leading idea is that, in relation with the literary field, the intellectual field is most sensitive to political changes and functions as a regulatory and legitimizing space for writers' everyday practices, via its power to produce the criteria for public recognition and thus for symbolic inclusion and exclusion. This casts a different look on the claims for creative autonomy within the cultural field and its multiple dependencies on media, politics, the civic and the academic field, and the understanding of the inner logic of these domains through the lens of their complex interrelationship.
\end{abstract}

Keywords: intellectuals, writers, cultural field, social networks, postsocialist transformations

\section{Introduction ${ }^{2}$}

The implosion of the Ceaușescu regime in December 1989, and the anti-communist turn of events, caught Romanian intellectual elites unprepared, suffocated as they were by more misery and a more oppressive dictatorship than other societies of the same socialist bloc. The collapse came as a surprise, as even the most optimistic expectations had been limited to reform from within à la Gorbachev. Signs of change, inspired by perestroika, precipitated some dissent and protests during 1988 and 1989: Cluj university professor Doina

\footnotetext{
${ }_{1}^{1}$ Sociology Department, Babeș-Bolyai University Cluj-Napoca, e-mail: mlazar59@yahoo.com.

2 The author expresses his gratitude for the attentive reading coming from Irina Livezeanu (who provided also competent insights and suggestions in structuring the content) and to Nancy Condee, Andreea Deciu, Emanuela Grama and Emanuela Petrescu, who provided useful comments of the first draft of this article.
} 
Cornea's critical letters to Nicolae Ceaușescu broadcasted by Radio Free Europe; the six former high level communist apparatchiks' open letter aired on March 10, 1989 on BBC, and poet Mircea Dinescu's March 17 devastating comments on Ceaușescu's cult of personality, in an interview for the French left-wing newspaper Libération, were all perceived as marks of dissidence and bravery, but not as decisive blows against the system. ${ }^{3}$ Most of these persons were placed under house arrest and heavy surveillance, were forbidden from appearing in public. Mircea Dinescu was fired from his post at România literară [Literary Romania]. In response, six other prominent members of the Writers' Union (WU) ${ }^{4}$ addressed a new letter in support of Dinescu (as well as Dan Deșliu and Ana Blandiana 5 ), to the Union's president. Ordinarily this would have been considered a merely internal, administrative complaint, but since the protesters were brought up on political charges, it too was received as a dissident gesture. Later, when the fall of the Berlin Wall confirmed the inevitable shift in the balance of power in Eastern Europe, such protests multiplied: two letters were sent to Radio Free Europe by another 18 young Romanian writers ${ }^{6}$ in November and December 1989 (Tănase, 2002: 153-154). These and several previous actions of public disobedience performed by Paul Goma, Gabriel Andreescu, Mihai Botez and Radu Filipescu, added to the small but now quickly growing pantheon of Romanian resistance to communism.

Intellectuals - mainly writers - became most prominent as dissidents ${ }^{7}$ but their initiatives did not really threaten the regime (Gabanyi, 2013). They were rather isolated and seemed almost to serve as proof of the lack of an organized revolutionary movement. When the bloody, violent revolution came, it was the absence of any coordinated intellectual involvement- like those in Poland, Czechoslovakia or Hungary- that stood out.

\footnotetext{
3 Silviu Brucan, Alexandru Bârlădeanu, Corneliu Mănescu, Constantin Pârvulescu, Gheorghe Apostol, Grigore Răceanu. Similar bitter protests came also in this period from the former prolecult writer Dan Deșliu.

${ }^{4}$ Geo Bogza, Ştefan Augustin Doinaş, Dan Hăulică, Octavian Paler, Andrei Pleşu, Alexandru Paleologu, Mihai Şora.

${ }^{5}$ Ana Blandiana suffered censorship after one of her books of poetry was discovered as bearing subversive messages.

6 The list includes Angela Marinescu, Anca Vasiliu, Anca Oroveanu, Andrei Cornea, Radu Bercea, Stelian Tănase, Ioan Buduca, Carmen Francesca Banciu, Gheorghe Iova, Dan Ciachir, Doru Mareş, Bogdan Ghiu, Alin Teodorescu, Dan Oprescu, Liviu Ioan Stoiciu, Mariana Marin, Dan Arsene, Magda Cârneci, Cristian Popescu, Gabriel Stănescu.

7 In the same period, Petre Mihai Băcanu, Anton Uncu, Mihai Creangă - journalists at România liberă, together with Alexandru Chivoiu (typographer), and the economists Elena Gheorghe and Ștefan Niculescu Maier were planning to set up a clandestine publication and were arrested; their case was less publicized
} 
The December revolution brought to power a group of mostly former apparatchiks gathered around the future president Ion Iliescu who stood at the core of a hastily arranged National Salvation Front (NSF). Iliescu, a former Communist Party dignitary, was known for opposing Ceaușescu in his last years. His semi-dissidence provided an ambiguous political capital in the postrevolutionary situation. This political capital would turn into a fundamental "bone of contention" for the emerging political field. While Iliescu and the NSF enjoyed acceptance during the first days after the fall of the communist regime, the consensus broke down as soon as Iliescu's supporters announced the NSF's intention to compete in elections as a distinct political organization. New political and civic factions formed and started to demonstrate publically against the "communist past" of various contenders and against the "neo-communism" of the new regime that was taking shape.

Through all this the intellectuals seemed to get lost "on their way to power," 8 (Konrad and Szelényi, 1979; Bozoki A. 1994; Antohi and Tismăneanu, V. 2000; King and Szelényi, 2004) to paraphrase Konrád and Szelényi, and their pre-revolutionary prominence faded amid the human sacrifice of ordinary people in the streets. In order to be able to maintain their claim to moral authority, they then embarked on a new legitimation process. However, a double inferiority complex - internal and external- made their quest precarious.

We might best understand what happened with intellectuals, artists and writers in Romania after 1989 in terms of emotional shock, a frustrating sense of inadequacy, and the coping strategies meant to allay these. Most of the accounts that try to explain their tribulations share a certain psycho-cultural and passionate view of the process (Șiulea, 2003; Gavrilescu, 2006). ${ }^{9}$ But there is also a sociological way to make sense of it in terms of intellectuals' need for a kind of moral insurance that motivated their affiliations to new influence groups that emerged almost instantly from the revolution, creating a structural polarization of alternatives, and forcing almost everyone to take a unilateral stand.

Despite a certain journalistic interest in this topic, there are few social science analyses that are clearly defined theoretically and methodologically, and most of these focus on the socialist period. (Verdery, 1991; Gheorghiu, 2007;

\footnotetext{
8 The idea of a strong connection between the collapse of the socialist regimes in 1989 and an organized involvement of the intellectual new class as revolutionary trigger was one of the most common understandings of the post-communist shift in the early nineties - and this perception was widely assumed by Romanian intelligentsia, also.

${ }^{9}$ Another common approach is rather normative and self-legitimizing, fueled by the struggles within the cultural, ideological and/or artistic field, and is coming from the main actors involved.
} 
Gheorghiu, 2008; Dragomir, 2007; Macrea Toma, 2010; Vasile, 2010; Pălășan, Stan and Vasile, 2011; Gabanyi, 2013; Vasile, 2014; Matei, 2004; Gavrilescu, 2006), ${ }^{10}$ One area that has been investigated ${ }^{11}$ but needs further elaboration is the drastic decrease in the prestige of writers and the crisis in their working conditions and pay levels (see also Gheorghiu, 2007; Lazăr and Livezeanu, 2001).

Here I try to give a "nuts and bolts" for a sociological account of these transformations. I look at the moral stance of intellectual repositionings as forms of symbolic competition (Bourdieu, 1984a; Bourdieu, 1992), linking the reproductive strategies of older and newer members of the intelligentsia to the social networks and implicit groupings they were attracted to (Bourdieu, 1994a; Fuchs, 2009; Fuchs 2001a). Thus, I try to show a few mechanisms and the social logic behind the recomposition of the literary and the intellectual fields in a context of major political transformations by presenting and partially deconstructing a few topics pertaining to the issue of cultural change after 1989.

\section{The "intellectuals": social, professional and symbolic hierarchies}

At the centre of this paper sits the figure of the "intellectual." Some refer to intellectuals as "a dominated fraction of the dominant class" (Bourdieu, 1996; Bourdieu 1984b; Kurzman and Owens, 2002; Kurzman, 2009) , as detainers of "symbolic power" - the ability of naming and defining the public (social, political, moral) agenda in an influential manner - and as an authority legitimized by cultural and symbolic capital more than by their economic status. Often, the intellectual's capital consists in publishing influential books, studies or articles rather than in simply having a higher degree. It is representative mostly of written culture, which generates this type of symbolic producer as opposed to audiovisual culture. But this does not limit the intellectual's renown from being spread by all the media and from becoming part of an influential "mediacracy." Whether s/he is a scholar, a writer, a "critical," or a "public

\footnotetext{
10 For the period after 1989, changes in the intellectual field were the subject of more extensive treatment by Matei, 2004) through critical analysis of the hegemony of "prestige groups" in the essayistic-philosophical-literary space; by Irina Livezeanu in her papers on postcommunist intellectual debates about the recent past, and on the adjustments in the field of history during the transition period in Romania; and by Adrian Gavrilescu, in a well-informed piece on the self-affirmation strategies of public intellectuals, that denounces the "complicities linking the combatant nuclei to our market of ideas."

${ }^{11}$ Contributions to a sociology of intellectuals include those on the legitimizing discourse of the members of the Group for Social Dialogue (Gheorghiu 2006, 2007; Runceanu, 2008); on the change of ideological codes by agents from the literary field after 1989 (Gheorghiu, 2007); and a pioneering investigation conducted in 1997 by members of the Sociology Department at the Babes-Bolyai University on writers in transition in Cluj (Culic and Lazar, 1997).
} 
intellectual," due to these attributes, s/he enjoys a certain prestige and public appreciation, being recognized as a pertinent authority whose opinion is often considered and questioned. Secondly, "the intellectual field" is meant to describe the area in which intellectuals act, a ubiquitous and multifaceted domain, which is not fixed but - like any battlefield - takes the form and follows the place of public confrontations (Bourdieu, 1966; Bourdieu, 1984b). The profile, the content, and the limits of this field cannot be prescribed and is defined only by the moving content and agenda of public debate. These definitions thus often remain ambiguous and contextual. In Eastern Europe they hark back to the ambiguities in the social perception of the class system and to the ambiguities of the social transformations, ${ }^{12}$ both in socialism and postsocialism: the intellectual is a by-product of these ambiguities and the struggle to construct a distinctive social identity on behalf of a segment of the ruling class (Bourdieu, 1984b; Lazăr, 1999).

The positioning of writers, intellectuals and artists in the socialist system was made through a system of formalized institutional benchmarks: basically, they were treated by the Communist Party as a coopted segment of charismatic or highly skilled experts, strongly needed by the propaganda apparatus, which have to be treated cautiously. ${ }^{13}$ But they were officially affiliated to schools (teachers), research centres (researchers), creative guild associations (Unions of writers and artists), cultural magazines, newspapers or publishing houses. Their recruitment and hierarchies within these fields were politically controlled more or less severe by the "Cadres" files (socialist equivalent of contemporary human resources offices). They were all integrated, in a sense, in the system of party "cadres" - and their problems were addressed by the political leadership of the party as both internal bureaucratic problems, regardless of their affiliation (artists or journal editors who were not party members were tolerated: it was assumed that they tacitly adhere to the party's ideology and are part of the political system as a whole) ${ }^{14}$.

In addition, the party's ideological production system operated at all levels of the nomenklatura - through "cadres" schools and party schools, all related to the core of the communist ideological apparatus should be noted (see also Tolz,

\footnotetext{
12 See the analysis of the two social ontologies of socialism (Lazar, 2011).

${ }^{13}$ See the description of the Communist Party's strategies for attracting and subordinating the writers and artists (they were labeled altogether as „intellectuals” by the party bureaucrats) to the propaganda apparatus (Macrea Toma, 2010; Vasile, 2010; Vasile, 2011)

14 Independent artists or autonomous intellectuals barely existed - and only a few artists or musicians are declared "free professionals" and fall into this category. Basically, in 1989, almost all the protagonists of the changes within the cultural field - with pretty fair few exceptions, such as Bogdan Ghiu or, somehow, Adrian Marino - were part of the system and, implicitly, part of the official hierarchic system.
} 
2004). Between these two systems there was some overlap. Leading positions were generally reserved for the activists, although this varied over time, the degree of liberalism within the system and the level of institutional autonomy fluctuating through the period of Stalinist proletcultism, the thaw in the 1960's, and gradually a re-politicization and ideological control in the midst 1970's.

\section{Literary or artistic autonomy}

The autonomy of the literary or artistic field is already inscribed in the institutional framework of socialist society, based on two preconditions. On the one hand, the human resources deficit of the regime makes necessary a permanent and external recruitment of "intellectual cadres". These are chosen from the higher educational system, the network of "art schools" (which became in time part of a generalized official establishment), or recruited among the artistic elite and intelligentsia of the old regime - of course, after some measures of ideological control and political enrolment were already taken. These measures might be varying from professional quarantine to political imprisonment and forced ideological conversions. On the other hand, special treatment and a degree of professional freedom is taken from granted as a precondition ${ }^{15}$. The basic idea of professional, literary or artistic autonomy had never been at stake in itself, but the margins of this autonomy and the legitimate limits of the ideological control. A permanent negotiation of autonomy was part of the game and was accepted by the communist apparatus as somehow legitimate. This justified a certain margin of dissent (as opposed to ideological conformism) on the behalf of the creative intelligentsia and also warranted a certain tolerance (as opposed to political intransigence) manifested in different ways and times by the bureaucrats dealing with "the problem of the art and culture sector", as the domain was officially framed.

To some extent, both the dissidence and liberalism were always there, depending on the players and on how coercive the rules were ${ }^{16}$. As in any strategic game, the partners play for their own interests. For the communist

\footnotetext{
15 See the material and professional conditions, for example, granted during the socialist regime for writes and artist that could be interpreted as social privilege also, if compared to the standard working people, condition which made them be labeled as a priviligentsia by some critics (Macrea Toma, 2010; see also Gabanyi, 2010, Vasile, 2010 and Vasile, 2014)

16 As Petru Negură put it, related to members of Writer's Union from Moldova, intellectuals were "neither heroes, nor traitors", because the higher the power position they could occupy within the political system, the larger their margins of liberalism, in opinion or actions, they could access (Negură, 2014). See further the presentation of Adrian Păunescu's case.
} 
leadership, at stake was an indefinite extension of their control if they could determine everyone to accept as settled the idea of the permanent leading role of the Party. For intellectuals, out of petty immediate advantages, at stake was the opportunity to design alternative cultural models and, of course, an effective persuasion to enforce them. During the negotiations, each partner hoped to lure the other - and each appealed to tactics meant to weaken the vigilance or misguide the opponent. And on each side, depending on the ability to control and impose homogeneity to the entire team, appeared partners willing to transact and gain personal advantage - material or symbolic. Therefore, the fight is not only over victory at the expense of the other, but is over maintaining control over the game by controlling one's own group. The Party addressed the problem of cultural producers as if they were a "cadre" problem, while intellectuals used, when appropriate, either patriotism, ethics as well as cultural ambitions or vanity of nomenklatura members, to redefine the situation in their own interest. That is why radicalized opponents of the regime (like Goma, for instance) could not gain support inside institutions such as the Writer's Union: they were jeopardizing the very basis of the writers privileges, not easily gained by a cultural elite whose creative autonomy was to some extent accepted by the government. Thus, protesters not only were not supported, but they faced hostility or indifference from fellow writers. Literary dissent was rare in the early stages of postStalinism.

The balance breaks down after 1977-78, when the communist leadership itself was no longer able to abide by the pact and tried to drastically limit cultural autonomy, already quite limited. The idea of protest and dissent started to gain attention. During the 1980s, when the general situation in Romania became increasingly critical and the freedom of speech further limited, emigration became the most common form of opposition, an extreme, desperate solution, whereby writers risked a complete loss of artistic identity. The intellectual "haemorrhage" of the 1980s and the multiplication of gestures of open dissent after 1987 were symptoms of a growing crisis in the pact between the communist political power and the intellectuals. They indicate the decomposition of the literary field itself before 1989 and before it became visible in the post-1989 "transition" era. But the Revolution of 1989 came over before intelligentsia's attitudes radicalized and "snowballed" to potentially make them initiators of the change. The generalized self-culpability that followed was a belated response to the sense of resignation and helplessness experienced during the hardest years of dictatorship.

The transformations of the Eastern European societies after 1989 brought out, surprisingly, a diminished status for the writers, artists and intellectuals, as compared with their positions held in socialist times (Lazăr and Livezeanu, 
2001). Largely acclaimed as main agents of the political resistance or heroes of the mobilization that lead to the revolutionary change, these exemplary social echelons were among the first to experience deception and decay. Writers, for example, „were not needed [any more] to defend the nation's very right to exist [...], nor were they needed as the voice of conscience in oppressive regimes" as one of the authorized connoisseurs of the region notice (Wachtel, 2003:5). "The creation of fledgling civil societies, democratic governments, and market economies in East European countries brought an end to the «objective conditions» that had placed writers on a pedestal for a century and a half" (Wachtel, 2003: 5). More explicitly, in Romania, the collapse of the old socialist system of editorial production and distribution of books and the adjustment of the production of new entrepreneurs, now private, to the requirements of the market economy, lead to both the diversification of the editorial offer and a progressive decrease of the number of copies published at national level, together with a drastic decrease in the prestige of the belletrist author and an acute worsening of his/her working conditions and pay levels (Gheorghiu, 2007, Lazăr and Livezeanu, 2001, Wachtel, 2003; Wachtel, 2006). Other areas - such as print and audiovisual media or higher education - have, however, known an upward dynamic, constituted as the poles of attraction for the subjects rejected by the contraction of the literary field, whose alterations in trajectory towards the most accessible areas in terms of types of accumulated capital (educational, symbolic, civic or political) are accompanied by specific conversion movements.

\section{Competitions within and outside the field}

The ambivalent position of the writer within the power system of socialism explains the permanent distress of the literary and artistic field as a tolerated continuous competition among artistic producers. It also explains why, during the confrontations over expanded autonomy, actors were competing each other in groups that were opposing not only artists on one side and party bureaucrats on the other, but in mixed teams of artists and bureaucrats, in each camp. "Us" and "them" always comprises composite squads of artists/ writers/ intellectuals, professional Party activists and administrative bureaucrats, on all fronts.

A confirmation of this elementary - but after 1989 intensely denied fact is an episode following the first months of the collapse of the regime of Ceaussescu. At the time, the bloody repression of the protesters of Timișoara and Bucharest in December 1989 led to a collective political trial, of the former 
members of Executive Political Committee of Communist Party (CPex). Among them was Gogu Rădulescu, a high ranking nomenklatura member, who was close to members of the cultural elite. Ion Ianoși in his memoir summarized what happened next:

\begin{abstract}
On the initiative - or with the consent - of writers who were close to him, intellectuals drafted a memorandum .... The text stated that Gogu Rădulescu continued to maintain contact, "especially in the last decade", with "a number of prominent intellectuals, some of them dissidents, helping them as much as he could and absolutely disinterested", and he supported also "in the more distant past, personalities of national culture marginalized or oppressed by the regime, such as Arghezi, Noica, Maria Tănase, Victor Slăvescu, S. Cioculescu and many others. (...) Gogu Radulescu saved some lives in the most ad literam meaning. (...) In recent years, dozens of writers, painters, and musicians benefited from his generous attitude, either managing to honour invitations abroad thanks to the signature of Gogu Rădulescu, their claims being repeatedly rejected by the passport office - or getting through his intervention of solving difficult and sometimes dramatic life problems(Ianoși, 2012: 697-698).
\end{abstract}

Thirty five prominent members of the intelligentsia, fellows of the Writers' Union or Artists' Union, ${ }^{17}$ (some of them, like Mircea Dinescu, Dan Hăulică or Alexandru Paleologu had been dissidents) - signed this memorandum. Rădulescu benefited later of some clemency as a result. The case is interesting because it reveals the role played by politically well positioned figures as negotiators from within - or brokers linked to personal and informal networks transgressing institutional affiliations, in the sense described by Barbara Walker and Vera Tolz for the early communist Soviet literary world (Tolz, 2004; Walker, 2004; Tomoff, 2004).

This support for a former member of the most stigmatized political organization of the time reflects the ambiguous position held until then by intellectuals within the communist system: the same people that condemned communism and the Ceaușescu regime in the harshest terms were also trying to rescue an exponent of their network. It is also a confirmation that the social network protects itself beyond ideological criteria; it proves that group solidarity is more important as a resource for survival and reproduction of positions than it is the ideological principle that is supposed unifying the group.

\footnotetext{
17 The entire list is: Geo Bogza, Augustin Buzura, Zigu Ornea, Nicolae Manolescu, Mihai Giugariu, Dan Setlacec, Ana Blandiana, Acad. Al Rosetti, Eugen Simion, Dan Hăulică, Dan Grigore, Cristian Mandeal, Valentin Gheorghiu, Ştefan Gheorghiu, Romulus Rusan, Cristina Angelescu, Cristian Popişteanu, Valeria Seciu, Adina Darian, Voichiţa Ivaşcu, Ing. Horia Cosma, F. Boeraş, Gabriel Dimisianu, Horia Andreescu, Al. Paleologu, Radu Cosaşu, Dan C. Mihăilescu, Tania Radu, Ion Ianoși, Anemone Latzina, Szász János, Mircea Dinescu, Marin Sorescu, Marta Camarache, Dinu Cernescu (Ianoși, 2012).
} 
This example shows how "cultural change" and the "transition" worked. On the one hand, the process is often described as a fight between former communist and new anti- or post-communist "forces" - as a confrontation between two ideologically split camps. On the other hand, on close examination, it exposes a complex world of groups and groupings, multiple interactions, multiple dependencies and individualized strategies, which make the entire picture more diffuse and puzzling. The persistence of these groupings after 1989 suggests a relative continuity between pre- and post-Revolution intellectual social worlds. Change may be recognized in terms of innovative forms of placing actors within networks on alignments which reproduce the group frontiers in a new context. Shifting contexts modify the form and configuration of confrontations, their modes of legitimation and the positions at stake, but not the opponents.

\section{Networks, groups and politics: "social dialogue" in the heart of elitism}

When the revolution exploded in December 1989 writers were mobilized to discuss their urgent problems at the Writer's House: on December 21 - the day of Ceaușescu's last speech, when the guns began to be heard in Bucharest, following those heard four days earlier in Timișoara. But nothing important happened that day. Some representatives of the (then) younger generation (Florin Iaru, Stelian Tănase, Dan Pavel) remember going to see what was happenning in the capital and were caught by the police together with other protesters. Then they became "revolutionaries" - and the next day, Pavel and Tănase were among the demonstrators cheering the flight of Ceaușescu by helicopter, and occupying the Central Committee building. The same day, at the newly proclaimed "Free Romanian Television", Ion Iliescu, revolutionaries and former dissidents, some of them coming straight from house arrest, announced the coming at power of the National Salvation Front. On December 22, in another gathering at the Writer's House, the president of the Writers' Union, D. R. Popescu resigned, assuming responsibility for the obstructive politics he had carried out since 1981, to block the Writers' Union committees and suffocate protests. Later, on December 28, a new leading committee was formed (Comitetul provizoriu al Uniunii Scriitorilor), with the following membership: Mircea Dinescu-president; Ana Blandiana, Dan Deşliu, Ştefan Augustin Doinaş, Domokos Géza, Octavian Paler, Eugen Simion, Stelian Tănase, and Dan Hăulică as spokesman. With Stelian Tănase's exception (he hasn't been yet even a member of the Union) all the fellows of this new leadership were either intellectual dissidents (as Dinescu, Blandiana, Deșliu, Doinaș, Paler, Hăulică), or respected members of the Union like Simion and the Hungarian minority representative, Domokos Geza. 
This was an important signal to the artistic and intellectual community: the writers eliminated the "Ceaușist" leadership and regained dignity by lining up behind the few symbols of Romanian resistance. They used this manoeuvre to confirm their opposition to Ceaușescu and the prestige of their guild. 18

In the first days after the Revolution, dissidents were celebrated everywhere and invited to enter the new editorial teams of now free literary publications. "Compromised" members and "collaborators" were purged - and, inevitably, the latter founded new publications. But the whole press, old and new, daily or weekly, political or artistic, joined the NSF and the revolution. Everything associated with Ceaușescu was stigmatized - and everybody made claims and complaints. Symbolic competition for grabbing and showing off moral capital, as well as for capitalizing on accumulated prestige, prevailed. "Resisters" and "dissidents", or just rank and file actors on the cultural scene, had all shared and now gradually detached themselves from - the culture of socialism. Most of them also denied belonging to the official hierarchy, proposing instead symbolic hierarchies and moral, rather than formal, biographies. These new bios were the effect of the capitalization of social prestige and moral order that instituted a different sort of legitimate hierarchy.

Table 1.

\section{Types of cultural producers, degree of politicization and intellectual or literary autonomy before 1989}

\begin{tabular}{|l|l|l|l|}
\hline & \multicolumn{1}{|c|}{$\begin{array}{c}\text { Party-affiliated } \\
\text { (Communist Party) }\end{array}$} & $\begin{array}{c}\text { Not party-affiliated - } \\
\text { Internal }\end{array}$ & \multicolumn{1}{c|}{ Diaspora } \\
\hline Literary field & $\begin{array}{l}\text { Official propaganda } \\
\text { writers (1950's socialist } \\
\text { realists); „Săptămîna” } \\
\text { magazine (E. Barbu, } \\
\text { CV. Tudor); A. Păunescu - } \\
\text { late 1970's, 1980's }\end{array}$ & $\begin{array}{l}\text { Autonomous writers } \\
\text { lyrics and poetry, novel) - } \\
\text { maximum autonomy: late } \\
\text { 1960's until early 1980's }\end{array}$ & $\begin{array}{l}\text { Independent writers } \\
\text { (i.e. Eugen Ionescu, } \\
\text { Vintilă Horia) }\end{array}$ \\
\hline $\begin{array}{l}\text { Literary and } \\
\text { intellectual } \\
\text { field }\end{array}$ & $\begin{array}{l}\text { Ideologues of socialist } \\
\text { realism, zhdanovists, } \\
\text { “protochronists”, } \\
\text { censors. }\end{array}$ & $\begin{array}{l}\text { - Literary critics } \\
\text { (N. Manolescu, } \\
\text { E. Simion, M. Iorgulescu) } \\
\text { - Essayists (Liiceanu, } \\
\text { Pleșu, Păltiniș school) }\end{array}$ & $\begin{array}{l}\text { Radio “Free Europe” } \\
\text { literary critics } \\
\text { (Monica Lovinescu, } \\
\text { Virgil Ierunca) }\end{array}$ \\
\hline $\begin{array}{l}\text { Intellectual } \\
\text { field }\end{array}$ & Political propagandists & $\begin{array}{l}\text { Independent thinkers } \\
\text { surviving interwar period } \\
\text { (Noica, N. Steinhardt) }\end{array}$ & $\begin{array}{l}\text { M. Eliade, E. Cioran } \\
\text { etc. }\end{array}$ \\
\hline
\end{tabular}

\footnotetext{
18 Perhaps for the same motive, the Writers' Union was never reformed properly. After a new conference held in the same year, the leadership of Writers' Union remained in the same hands, mostly, and with the same organizational principles, dysfunctional within the economic changes of the transition, unable to maintain the professional standards or create a solidarity among its members as it happened before.
} 
But many writers were stigmatized in 1989. One example is the poet Adrian Păunescu. The complete opposite of Gogu Rădulescu, Păunescu, a prolific and very talented poet, was acclaimed by a public that he had himself created through Cenaclul Flacăra (the Flame poetry group) a vast popular pageant of music, art and political propaganda he ran from 1973 to 1985 (Mocănescu, 2011: 95). His huge popularity and charisma made him one of the most effective propagandists of the Ceaușescu regime and transformed his show - held in stadium full of young people - into an important vehicle of a nationalism that increasingly displaced Marxism Leninism in the official discourse. An editor of the important wide-circulation magazine Flacăra, his triple success as poet, journalist, and propagandist made him politically influential. Other writers kept their distance from him. In the Cenaclul Flacăra show Păunescu often flattered the "Supreme Leader" and enjoyed political and symbolic favours in return (Gabanyi, 2013). Păunescu was thus in a position to intervene for some of his colleagues in distress, for instance when Marin Sorescu lost his position as editor in chief of the revue Ramuri (Branches) and his right to sign, being involved in a Securitate murky provocation (Gabanyi, 2013). But Păunescu remained stigmatized by the writers' guild after the revolution; he was labelled a "court poet" and collaborator, and eventually ended up rallying the former Communist high executive of the Communist Party, Ilie Verdeț (ex-prime minister of Romania under Ceaușescu) as a founder of Partidul Socialist al Muncii [the Socialist Party of Labour]. This party strangely associated with the radical nationalists of Partidul Romania Mare [the Greater Romania Party] led by Corneliu Vadim Tudor. Finally, Păunescu joined Partidul Social-Democrat [the Social-Democratic Party], the last public face of the former National Salvation Front in solidarity with Ion Iliescu.

Table 2.

Types of cultural producers, their degree of politicization
and autonomy - 1990-2004

\begin{tabular}{|l|l|l|}
\hline & $\begin{array}{l}\text { Party-affiliated } \\
\text { (multiparty system) }\end{array}$ & $\begin{array}{l}\text { Not party-affiliated internal and } \\
\text { Diaspora }\end{array}$ \\
\hline Literary field & $\begin{array}{l}\text { Stelian Tănase (PAC, PNL 93), } \\
\text { Augustin Buzura (FSN), } \\
\text { CV. Tudor (Greater Romania Party), } \\
\text { A. Păunescu (PSD, PSD) }\end{array}$ & $\begin{array}{l}\text { Autonomous writers facing } \\
\text { economic decomposition of } \\
\text { the field; market dependency }\end{array}$ \\
\hline $\begin{array}{l}\text { Literary and } \\
\text { intellectual field }\end{array}$ & $\begin{array}{l}\text { N. Manolescu - political career } \\
\text { (PAC, PNL) } \\
\text { Al. Paleologu (PNL) }\end{array}$ & $\begin{array}{l}\text { Literary critics (E. Simion, } \\
\text { M. Iorgulescu, Al. Cistelecan) } \\
\text { Essayists (Liiceanu, Pleșu, Patapievici) }\end{array}$ \\
\hline $\begin{array}{l}\text { Intellectual } \\
\text { field }\end{array}$ & $\begin{array}{l}\text { AC (Civic Alliance) - nonparty } \\
\text { Democratic Convention }\end{array}$ & $\begin{array}{l}\text { GDS (Group for Social Dialogue } \\
\text { RAS (Romanian Academic Society - } \\
\text { Alina Mungiu) } \\
\text { NEC (New Europe College) }\end{array}$ \\
\hline
\end{tabular}


The writer Eugen Barbu, the former director of the weekly publication Săptămâna culturală a Capitalei [The Cultural Week of the Capital], and the younger poet Corneliu Vadim Tudor, Barbu's right hand man were similarly stigmatized. Both were hated for their political denunciations, for public defamation of many writers who had faced difficult political position and the calumnious tone of their weekly. Barbu was a member of the Party Central Committee but was at war with the whole Writers' Union since 1979 because of plagiarism accusations regarding some of his novels. The Union condemned the plagiarism - and Barbu threatened to leave the Communist Party in protest. But he did not. After that, he and his publication were used occasionally by the tough wing of the propaganda apparatus (nationalist, anti-Semitic, strongly xenophobic) against the broadcasters of Radio Free Europe - especially Monica Lovinescu, Virgil Ierunca and other exiled Romanian writers. Barbu was the first to be excluded from the Writers' Union in 1990.

A pall fell upon Eugen Barbu and Corneliu Vadim Tudor. Their names could not appear in any publication, in spite of the heated political context of the first year of freedom. The ban ended in august 1990, when Corneliu Vadim Tudor obtained from Iliescu's Government subsidies for a new publication, România Mare [Greater Romania], which was stridently xenophobic, racist, anti-Semitic, anti-Hungarian, antidemocratic, apologetic for the prior Securitate and the Ceaușescu regime, poorly and scandalously written - and in the business of the moral assassination of former anti-communist opposition. Barbu became shadowed in this new arrangement. Soon, most of the former dissident writers and Barbu's enemies - together with the representatives of the new civic organizations opposing FSN - were again under attack. In 1991 Corneliu Vadim Tudor founded the Greater Romania Party and was co-opted into the government coalition, along with the former FSN (now FDSN), the National Unity Party of Romanians (PUNR), gathering mainly Romanian nationalists from Transylvania, and the Socialist Party of Labour (PSD) of the former communist nomenklatura. Thus a cultural (mainly writers') opposition was in part shaping the political field. Twenty years later the reverse would happen.

\section{The Group for Social Dialogue and the Intellectual power utopia}

The writers' aura was endangered after the revolution by the new economic conditions and the emergence of a new segment of the cultural field - that of civic intellectuals. In December 1989 Grupul pentru Dialog Social [the Group for Social Dialogue - GSD], made its entrance. An informal grouping at first, GSD was to exert a tremendous influence in the post-revolution public life, cementing the political opposition around a civic project. 
GSD was founded in the early days of the revolution around the networking efforts of Mihnea Berindei, president of the French Committee for Human Rights in Romania. ${ }^{19}$ Immediately after entering the country on 1989 December 22 with several aid trucks, Berindei contacted a number of Romanian dissidents - Mariana Celac (December 23), Radu Filipescu (December 28) and Gabriel Andreescu who, apparently, put Berindei in contact with Andrei Pleşu and Gabriel Liiceanu. Berindei also contacted Ștefan Augustin Doinaș, Alexandru Paleologu and Stelian Tănase. On December 29, the Romanian Television announced that a "group for reflection" that included Andrei Pleșu, Octavian Paler, Alexandru Paleologu, and Gabrel Liiceanu was established (Răduță, 2005). The contrast created by these austere intellectuals to the disarticulated and chaotic revolutionary discourses heard until then was huge. Liiceanu read that evening, on television, $A$ Call to Sycophants (lichele), in which he asked morally compromised members of the old regime (the sycophants) to step back and be silent.

The next day the Group for Social Dialogue announced its establishing in a press conference. GSD began publishing a weekly, 22 - the day in December 1989 the Romanian revolution had arisen. Its first issue of January 20 featured a Declaration of Principles. The group undertook a saving mission in almost post-apocalyptic terms: It aimed to represent the moral conscience of our humiliated and destroyed society. We want to contribute to overcoming the disaster and to regenerating our country". GSD affirmed its political independence from the NSF and the just re-emerged "historical" political parties (PNL, PNT, PSD), equally: "The Group for Social Dialogue is an independent and strictly informal group, it is not subordinated to any political party, that rejects any cooperation with anybody connected with the old regime" (see also Runceanu, 2008).

This statement represents a mix of missionary and enlightened program by which the intellectuals saw themselves at the symbolic centre of a society to be re-founded on moral bases. GSD imagined itself simultaneously as a sort of intellectual "Salvation Front" and group similar to KOR, as in 1970s Poland. The intellectuals proclaimed themselves representatives of "civil society" and

\footnotetext{
${ }^{19}$ Here is Berindei's telling about his networking action: "In December I came up with the idea to know these people, many of whom I had never seen. Meanwhile I knew Mariana Celac and Mihai Botez. On the evening of December 25 I called Mariana (I was with Anton and Ariadna Combes) there were still shootings, I managed to convince someone to drive us there. I was at the Intercontinental, I went through the back of the street, on Dacia Boulevard, I crossed two barrages and took Mariana with us: it was a huge moment. The next day at Andrei Pleşu (more exactly, at Ascanio Damian's place) I met many others. Then I went to look for Radu Filipescu and Gabriel Andreescu, I returned with them to Pleşu and so the GDS was done, in part. At St. Augustin Doinaş I met Alec Paleologu, who told me about Stelian Tanase and about another group (the 18 who had signed the letter). They had too the idea of a GDS, which quickly took shape." (Revista 22, No. 30(21): 9).
} 
contributed to its reconstruction, keeping their distance from politics ("The group does not wish to be a centre of power, but a centre of influence" - says the Declaration).

Such GSD statements reveal an imagery of power and symbolic dominance that construct retrospectively what intellectuals thought should have happened before 1989 - but did not. They express also a wishful selfaffiliation to a noble tradition of resistance organized by East-European intellectuals in late communism. It is a fictional group-biography and post-hoc action taking, which turns their public interventions into a normative, regulative stance. The ideal of pre-revolutionary solidarity and resistance, imagined following other East-European models considered successful, became a measure for what should now happen in Romania, after the fall of communism. This attitude suggests a prevalent inferiority complex, associated with a need to change the past: actions planned for the present intended, involuntarily, to correct history. They also trace the contours of a constant anti-communist attitude that became the Group's main political mark and criterion for public position taking for years to come ${ }^{20}$.

The background of GSD members was heterogeneous - and the January 1990 Declaration of principles itself look like a negotiated project, joining different perspectives and mixed ideologies: conservatism and anticommunism coexisted with a social emancipatory and constructivist project. Political involvement, assumed at an individual level, was refused by the group as a whole. GSD expressed a general reluctance toward parties and "politicianism". Members of GSD joined the mass protests of January 1990. These were occasioned by the NSF declaring its intention to abandon a politically neutral position and run in elections that spring. "We are not parties" was the slogan under outstanding members of GSD regrouped in the streets, like thousands of others in Bucharest (Adameșteanu, 2014: 359).

\footnotetext{
20 A sociological survey I coordinated in 1997, based on standardized interviews carried out in the city of Cluj with local writers (Lazar and Culic, 1997) revealed a bipartite authority within the literary field of the ' $90 \mathrm{~s}$. When asked about the most prominent contemporary cultural personalities of the moment, the interviewees clustered around two kinds of options: one naming as key authoritative figures mainly the glorified leaders of literary field, and the other naming mostly essayists and intellectuals recognized as ideological trend-setters and civic opinion leaders. The literary field blended together two instances of legitimation: a literary one and an ideological one. The inner, autonomous, mechanism of recognition and promotion specific to the literary field before 1989 was slowly replaced by an external one, coming from the field of the new ideological debates set up by the 'intellectuals'. These findings encourage a parallel examination of the various recompositions of the political field after 1989, on one hand, and of the media, the intellectual, and the literary fields, on the other hand. In time, such recompositions reshape and restructure the former ideological divisions, and different intellectual groups become more and more aware of their biases, and more willing to acknowledge them openly.
} 
Yet, after the smashing victory of NSF and Iliescu, in May 1990, and the mass violence coordinated by NSF against the opposition (GSD included) in June, when large groups of miners from the Jiu Valley came to Bucharest to "put things in order" - GSD started to regroup as an opposition force. It inspired the creation of the Alianța Civică [Civic Alliance], which would be the expression of the outside-party way of being involved in big politics, in respect both for distancing from politics and assuming responsibility for the Romanian civil rights (Pavel, 2003). The Civic Alliance gathered the political opponents of Ion Iliescu for the 1992 and 1996 elections and it was an important factor for the success of the Democratic Convention in seizing power in 1996 (Runceanu, 2008). The symbolic capital intellectuals held within these double faced electoral arrangements: civic-based in exterior, and political in interior, was most effective in these political confrontations.

These evolutions brought an end to the civic momentum inside intellectual utopia. Instead, they were making room for a much engaged and open partybased political involvement, marked by inner struggles, which emphasized the heterogeneous nature of the genuine group. From the beginning, who was in and who was out was a term of dispute (Runceanu, 2008), even though the group was informal and (in theory) open. In fact, it held together political dissidents such as Gabriel Andreescu and Radu Filipescu, cultural dissidents such as Paleologu, Doinaș and architect Mariana Celac, prestigious philosophers or essayists such as Gabriel Liiceanu and Andrei Pleșu, members of the semidissident group of young writers from the so-called "generation '80" (Stelian Tănase, Magda Cârneci, Dan Pavel) and sociologists like Pavel Câmpeanu, Alin Teodorescu, Călin Anastasiu and many others. GSD was trying to harmonize different influences: one was supposed to come directly from NSF, from the powerful Silviu Brucan, who provided a premises for GSD (he was rewarded with a long interview in the first number of 22); Pavel Câmpeanu and the sociologists were presumed to be, at first "Brucan's people". Gabriel Andreescu and Radu Filipescu received the support of Mihnea Berindei and the French Committee for Human Rights Defence in Romania (very active since 1977); Monica Lovinescu and Virgil Ierunca, from the Romanian section of Radio Free Europe, supported Gabriel Liiceanu. Both of them had an enormous influence among writers. Stelian Tănase hailed from the group of young writers, who tried to line up in the last moment to the Eastern European changes that occurred after the Berlin wall fell down. All of them felt that "something has to be done" (Tănase, 2002: 153-154; Adameșteanu, 2014) ${ }^{21}$.

${ }^{21}$ It is the "letter of the 18 intellectuals" which was broadcast by RFE on December 18, after the protests started in Timisoara and people were already shot on the streets. The list includes Angela Marinescu, Anca Vasiliu, Anca Oroveanu, Andrei Cornea, Radu Bercea, Stelian Tănase, Ioan Buduca, Carmen Francesca Banciu, Gheorghe Iova, Dan Ciachir, Doru Mareș, Bogdan Ghiu, Alin Teodorescu, Dan Oprescu, Liviu Ioan Stoiciu, Mariana Marin, Dan Arsene, Magda Cârneci, Cristian Popescu, Gabriel Stănescu. 
So the general picture shows GSD as a nexus of different groups whose dissimilarities were at first harmonized through a discourse assuming a symbolic unity, but which eventually exploded inside GSD. The Group became a sounding for various kinds of interests: the Romanian emigration - which was split generationally and ideologically between the interwar political class, forced to emigrate at the end of World War II - and the new emigration that left during socialism; those who aspired to a renewed cultural legitimation and new resources for cultural prestige; those covering an uncomfortable past and who later would be discovered as collaborators of the political police; those prolonging their dissidence into a civic renewing project, etc.

These heterogeneous backgrounds and influences brought comments and disputes among the founding members, as they debated the GSD's position toward monarchy, political involvement, Romanian interwar far right, toward nationalism. In all these debates positions continued to polarize rather than come to a consensus. The 22 weekly reflected these dissensions from the beginning. Their echo amplified and started to erode the initial solidarity of the founders.

Figure 1 presents the diagram of confrontations between the main contributors, and it reveals the conflicting relationship of the core members of GSD in the first years of the organization (1990-1996) and the adversarial relations among each of them (depicted by lines), as monitored by time in the GDS official, 22 magazine. It is not about relations of adversity among GSD members, but about mutual disapproval and polemical exchange of ideas. The centre of this net of conflicts is occupied by Gabriel Andreescu - who tended to bear most of the polemics - Alina Mungiu and Stelian Tănase. All of them were excluded, in time, from GSD.

The positioning here of Andrei Pleșu, Gabriel Liiceanu and Andrei Cornea deserve a more detailed discussion, because their trajectory was received as a promise for an alternative culture to the institutionalized socialist system: under the political control, socialism could not produce outstanding outcomes (with a few exceptions), because it lacked the motivation for "a high-performance culture" and the cult of exceptionality, as these authors stated (Liiceanu, 1983). These were the words of philosopher Constantin Noica, whose disciples they were, their close relationship being described as an informal sort of "school", based in informal teaching and cultural transmission in a series a books signed by Gabriel Liiceanu. These books (The Păltinis Journal - 1983; Epistolary -1986) enjoyed a huge popularity in the literary and intellectual world and became a cult. Noica was a charismatic figure, a philosopher from the same generation of Emil Cioran, Mircea Eliade and Eugen Ionescu distinguished Romanian cultural émigrés - whose friend he was. 
Figure 1. Diagram of disagreements and confrontational relationships between members of the Group of Social Dialogue between 1990-1998.

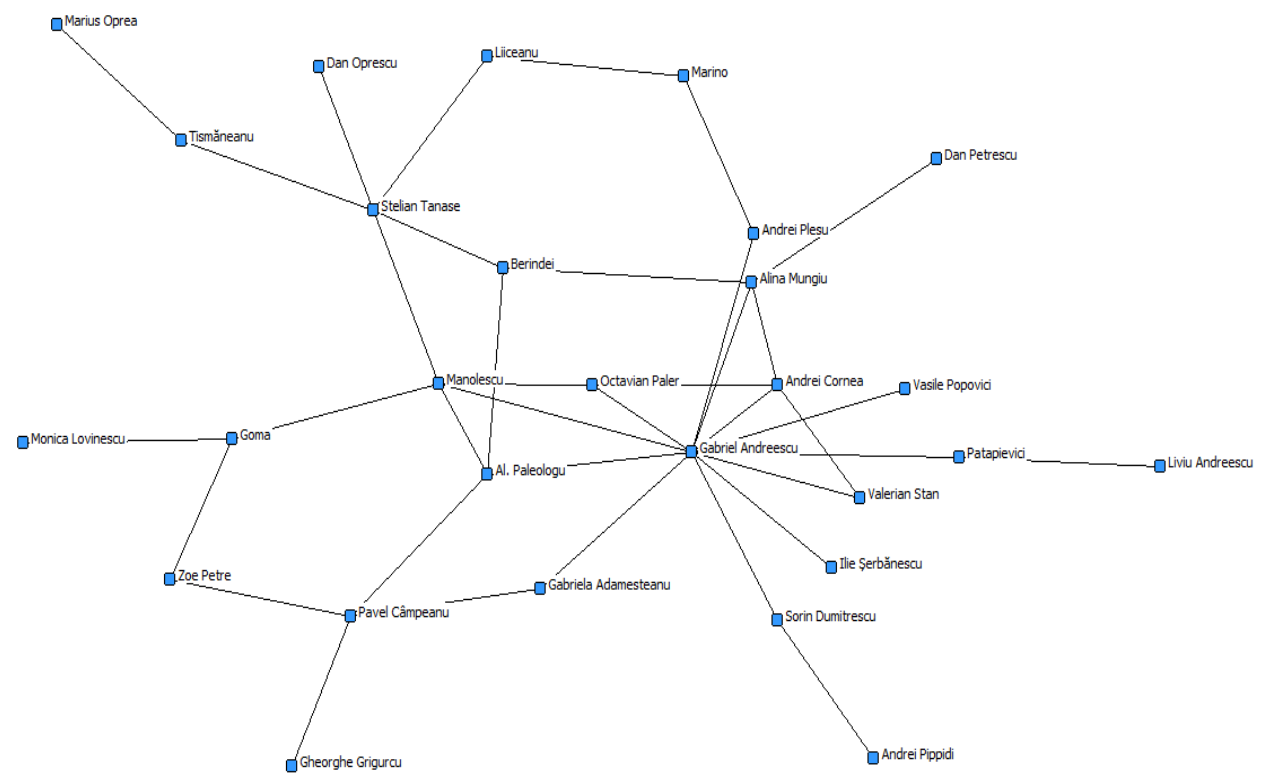

Noica's very ambitious work started in the 1930s, but was interrupted by political detention (was a member of the fascist Iron Gard). He accomplished as an ambitious and original philosophical synthesis, a Treatise of Ontology, which incorporates Romanian ethnocentric themes in a Hegelian and Heideggerian net of concepts. Withdrawing to a small mountain locality - like Heidegger -, at Păltiniș, Noica started to plead for a "Great Culture" in which the Greek and German classical philosophy set the standards. At the time he was also unsuccessfully - searching for 22 young geniuses in order to form a highlytrained cultural elite and he expected from the communist authorities to sponsor the project. As told by his disciples, Liiceanu and Plesu, his personality elicited a fascination from young generation of intellectuals and scholars. It soon became a cult: people from all over the country were visiting the philosopher, searching for crucial professional advice, a personal confirmation in career, an assessment.

In this respect, the "Paltinis school" challenged the dominant model of a literary-based culture, in which the writer and the literary critic were the central figures, proposing an elite philosophy oriented high culture, subversive, informal, external to the institutionalized system. This became both highly 
prestigious and dissident at the same time, raising extraordinary expectations for cultural renewal. Thus, the number 22 - which provided the title of the GSD periodical - acquired a new meaning, as a discrete marker of a new elite group, with a redeeming mission and exceptional destiny.

Gabriel Liiceanu, Andrei Plesu and Andrei Cornea were all involved in the creation of GSD - but, soon, Plesu did not consider himself a proper GSD member ${ }^{22}$, being coopted in the first NSF government (to which GSD was in opposition), as Minister of Culture (December 1989 - October 1991). Pleșu also disliked a certain intransigence that seemed to lead the members of GSD to a moral and political Manicheism. In 1993 he founded an alternative weekly magazine called Dilema. He considered this title would invite to calm, reflection and a balanced attitude. Noica's alternative elite project was realized finally as an Institute for Advanced Studies, New Europe College (NEC) ${ }^{23}$ - a private institution, connected to a European network of similar colleges based in Berlin, Vienna and Budapest. NEC recruited fellows in a strictly parsimonious way. The first cohorts graduating their programs re-enacted, coincidentally, the magic number of $22 \ldots$ Soon, NEC became a true school for elites and a basis for recruitment for different administrative positions, either cultural or political (the network of Institutes created after 1999, Romanian Cultural Institute, Ministry of External Affairs) during governments supported by GSD activists.

\section{A Politicized intellectual field}

The connection with the Romanian political cycle has to be mentioned 24 . After the Democratic Convention won the elections of 1996, it easily lost them in 2000. For another four years Iliescu and his followers held the power in an authoritative manner, often accused as suffocating the free circulation of opinion and boycotting the press. The Democratic Convention (DC) and the Civic Alliance collapsed altogether - and with them evaporated the whole project of a civic-intellectual filter of politics. This implied great losses for those involved in it.

\footnotetext{
22 Personal communication with Andrei Pleșu at NEC, Bucharest, 1999.

23 www.nec.ro. [Last accessed: 25.05.2015].

${ }^{24}$ Here is a short chronology of the main political course involving these regroupements: Petru Clej, Lingem acolo unde am scuipat - cronologie politică românească, in Acum, febuary 6, 2011, file:///C:/Users/Marius/Desktop/PITTSBURGH_INTELECTUALI/Cronologii/BĂSESCU/Lingem\% 20acolo\%20unde\%20am\%20scuipat\%20\%E2\%80\%93\%20cronologie\%20politic\%C4\%83\%20 rom\%C3\%A2neasc\%C4\%83\%20\%E2\%80\%94\%20ACUM.TV.htm [Last accessed: 25.05. 2015].
} 
The opposition regrouped around the National Liberal Party and the Democrat Party (a wing of NSF which defected from the Iliescu group and drew close of DC). Soon they formed another coalition, aiming to capitalize the former energy of the DC electorate. The new coalition was Alianta DA [Yes Alliance]. Former intellectual supporters of the Democratic Convention migrated to this new alliance, a movement which reproduced largely the former division that separated former NSF and the anti-communists.

While intellectual unity was temporarily maintained, an intense ideological polarization started. It was fuelled by controversies around the anti-modernist content of the writings of Andrei Pleșu, Gabriel Liiceanu and Horia Roman Patapievici - a new name cultivated by the 22 magazine, rapidly coopted among the former Păltiniș School members. At stake was also the hegemonic position the group started to occupy within the intellectual field. A book of Sorin Matei Adam (Matei 2004), insidiously titled Boierii minții [Boyars of the mind], which tried to explain sociologically the dominant position held by the Păltiniș school fellows, which saw them altogether as a Weberian status group, capitalizing on the cultural influence and controlling the "market of ideas", launched heated debates in the cultural media. In retaliation, the "Păltiniș school" members mobilized their devotees (some of NEC alumni among them) in order to display their public support. The so-called Intellectual quarrel (Cearta intelectualilor) occupied all the summer of 2004 and rekindled the next year. A polarizing division occurred within the intellectual field (Livezeanu, 2003). ${ }^{25}$ "Păltiniș school" members regrouped, started to speak about a new conservatism. They grew more vocal in asserting an anti-liberal ideology. Hence, ideological polarization fragmented the intellectual field and divided those positioned closer to liberalism or to conservatism (the last ones being recruited mostly among NEC and new GDS members).

The Yes Alliance won the elections of 2004 and Traian Băsescu, leader of the Democrat Party, became president. Andrei Pleșu was his presidential adviser, while Horia Roman Patapievici became president of Romanian Cultural Institute (Institutul Cultural Român - ICR). He replaced the novelist Augustin Buzura (close to former president Ion Iliescu). Soon, the relationship among the allies deteriorated and a huge gap occurred among the followers, intellectuals included. Traian Băsescu managed to gain the support of most GSD members and especially those close to Andrei Pleșu and Gabriel Liiceanu. In 2006 Băsescu officially condemned communism - an older demand of Romanian postcommunist intelligentsia - reading an incriminating report of a commission specially

25 Diagrams BI and BII show the space of mutual affinities and dissimilarities among the main debaters. 
instituted, coordinated by Vladimir Tismăneanu, a Romanian born professor at University of Maryland who left the country in the 1980s. These GDS intellectuals remained constant supporters of the President during the most difficult political moments he confronted ${ }^{26}$. The anti-presidential media labelled them as "Băsescu's intellectuals". Liberal opponents within the intellectual field positioned themselves, in all circumstances, against Băsescu and, implicitly, against "his" intellectual guard.

The intellectual field became thus politically marked. Research institutes dealing with the memory of Communism (ICCMER) and the Securitate Archives (CNSAS) - claimed by the civic intellectuals of the 90's and territorialized by them during the Democratic Convention and Yes Alliance governments, became terrains of disputes in which leading positions were symbolically and intellectually legitimized, but politically obtained (see also Adameșteanu, 2014). The cultural field lost its autonomy vis a vis politics. And this was exactly what the intellectuals of 1989 were fighting against.

\section{Conclusions}

Immediately after 1989 , the political changes in Romania engaged strong repositioning reactions on the behalf of those who until then were recognized as writers (novelists, poets, literary critics and essayists) and public figures. These repositionings were largely determined by the new political engagements for or against the renewed political power structures of the 1990s, controlled from the very beginning by a group clustered around a new leader, former high-ranking Communist Party official: Ion Iliescu. If in the first days after the fall of the communist regime in December 1989 a wide consensus against Ceaușescu as a leader and a person existed, this consensus was soon broken and various political parties and factions started to publicly manifest their divergent agendas, engaging different and often opposite values and world views.

Delegitimizing the previous regime immediately became one of the dominant patterns of self-assertion in the public sphere; so was demonizing the forms of "collaborationism", comparable to those of post-WWII France, described by Giselle Sapiro (Sapiro, 1999). These worked together with exhibiting the signs of former "dissidence", "disobedience" or "resistance". For intellectuals, "the resistance through culture" became the common self-legitimizing compensatory myth, a way of- re-appropriating an uncomfortable and most often silent past.

\footnotetext{
${ }^{26}$ http://www.ziare.com/politica/cotroceni/parabola-intelectualilor-lui-Băsescu-1298245; http://www.contributors.ro/cultura/o-ultima-precizare-despre-\%E2\%80\%9Eintelectualii-luiBăsescu\%E2\%80\%9D/[Last accessed: 25.05.2015].
} 
Intellectuals also were promoting a symbolic economy of classes, opposed to "objectivist" classification system (in Bourdieu's terms - see Bourdieu, 1984; Bourdieu, 1984b; Bourdieu, 1994a; Bourdieu, 1994b) of Marxist origin, with its standardized categories (workers, peasants, intellectuals) being handled in practice as homogeneous "blocks" and suppressing individual qualities. Thus they were in fact trying to substitute physical strength - objectified as a political force - with symbolic power and endorse moral principles as foundations for a new social order.

A need for a moral securitization motivated almost instantly the affiliation to the new influence groups emerging at the Revolution. The Revolution of 1989 created a utopia of the civic intellectual whose public intervention could change history and create more freedom. Civic and intellectual organizations were meant to objectify Havel's idea of a "power of the powerless" and were engaged in the transformations acting first of all upon the politics and trying to subordinate the political field to moral principles.

In this respect, the Group for Social Dialogue, gathering former dissidents or nonmainstream recognized intellectual leaders such as Gabriel Liiceanu and Andrei Plesu functioned as a gratification instance and source of personal and public confirmation (Gheorghiu, 2005; Răduță, 2005). Similarly, members of the Writers' Union, fighting for literary autonomy and opposing the ideological control of the literary field by the Communist Party, formed another influence group. Affiliations to these groups provided thereby the preconditions for acceptance within its own field of production - a sort of professional and moral "passport" regulating the social mechanism of inclusion and exclusion. Not being validated by these (politically pre-oriented) "moral" authorities meant risking access to the resources of professional recognition and ultimately total professional failure. But the decomposition of the literary field under the pressure of market economy and the suddenly diminished social prestige of writers subverted the autonomy of literary institution and made it vulnerable to external influence.

This is the way intellectual field started to function as a regulatory and legitimizing space for writers' everyday practices (like publishing or gaining appreciation), through its power to produce the criteria for public recognition and thus for symbolic inclusion and exclusion. Hence, if at first the literary field oppositions set the tone of public cultural debates, in time an increasingly politicized intellectual field tended to become the main instance of authority justifying or empowering publicly expressed opinions. Literary autonomy had to confront again, in different forms, the intrusion of ideology; a politicized cultural field started to be again organized by political divisions. 


\section{REFERENCES}

Adameșteanu, G. (2014). Anii romantici. Aminitiri, gânduri [The Romantic Years. Memories, Thoughts]. Iași: Polirom.

Antohi, S. and Tismăneanu, V. (2000). Between Past and Future: The Revolutions of 1989 and Their Aftermath. New York: Central European University Press.

Bourdieu, P. (1966). Champ intellectuel et projet créateur. Temps modernes, No. 246: 865-906.

Bourdieu, P. (1984a) [1979]. Distinction: A Social Critique of the Jugement of Taste. (Richard Nice, trans.) Cambridge MA: Harvard University Press.

Bourdieu, P. (1984b). Homo academicus. Paris : Les Éditions de Minuit.

Bourdieu, P. (1992). Les règles de l'art. Genèse et structure du champ littéraire. Paris: Les éditions du Seuil.

Bourdieu, P. (1994a). Strategies de reproduction et modes de domination. Actes de la recherches en sciences sociales, No. 105: 3-12.

Bourdieu, P. (1994b). Raisons pratiques: sur la théorie de l'action. Paris: Les éditions du Seuil.

Bozoki, A. (1994). Intellectuals and democratization in Hungary. In C. Rootes and H. Davis (eds.): Social Change and Political Transformation. London: UCL Press.

Dragomir, L. (2007). L'Union des écrivains. Une institution transnationale à l'Est: l'exemple roumain. Paris: Belin,

Fuchs, S. (2009). The Behavior of Cultural Networks. Soziale Systeme 15, Heft 2.

Fuchs, S. (2001a). Beyond Agency. Sociological Theory, 19(1): 24-40.

Fuchs, S. (2001b). Against Essentialism: A Theory of Culture and Society. MA: Harvard University Press.

Gabanyi, A. U. (2013). Ceauşescu şi scriitorii: analize politico-literare în timp real [Ceaușescu and the writers: real-time political and literary analyses]. Iași: Editura Universităţii „Al. I. Cuza”.

Gavrilescu, A. (2006). Noii precupeți. Intelectualii publici din România de după 1989 [New entrepreneurs. Romanian public intellectuals after 1989]. București: Compania.

Gheorghiu, M. D. (eds). (2005a). Littérature et pouvoir symbolique. București: Ed. Paralela 45

Gheorghiu, M. D. (2005b). Le Groupe de Dialogue Social et les intellectuels roumains « libres » après 1989. In M.D. Gheorghiu (ed.): Littérature et pouvoir symbolique, București: Ed. Paralela 45.

Gheorghiu, M. D. (2007). Intelectualii în cîmpul puterii. Morfologii și traiectorii sociale [Intellectuals in the field of power. Morphologies and social trajectories]. Iași: Polirom.

Gheorghiu, M. D. and Lupu M. (eds.) (2008). Mobilitatea elitelor în România secolului al XX-lea [The mobility of Romanian elite in the 19th century]. București: Ed. Paralela 45.

Ianoși, I. (2012). Internaționala mea. Cronica unei vieți [My International. The Chronicle of a Life]. Iași: Polirom. 
King, L. P. and Szelényi, I. (2004). Theories of the New Class: Intellectuals and Power. Minneapolis: University of Minnesota Press.

Konrad, G. and Szelényi, I. (1979). The Intellectuals on the Road to Class Power: A Sociological Study of the Role of the Intelligentsia in Socialism. New York: Harcourt Brace Jovanovich.

Kurzman, C. and Owens, L. (2002). The Sociology of Intellectuals. Annual Review of Sociology, 28: 63-90.

Kurzman, C. (2008). Democracy Denied, 1905-1915: Intellectuals and the Fate of Democracy. Cambridge MA: Harvard University Press.

Lazăr, M. and Culic, I. (1997). Writers in transition. A sociological survey on the changes in the literary filed of Cluj Napoca, 1997 (unpublished manuscript).

Lazăr, M. (1999). Structuri politice şi cultură: Cîmpul cultural de la "destalinizare" la mitul "salvării prin cultură" [Political structures and culture: the cultural field from destalinization to the "salvation" through culture myth]. Xenopoliana, VII: $169-195$.

Lazăr, M. and Livezeanu, I. (2000). Remaining Relevant after Communism. Research Report for Romania (unpublished manuscript).

Lazar, M. (2011). Classe, mobilité et stratégies de conversion dans le champ intellectuel de Roumanie après 1989. In M. D. Gheorghiu (ed.): La mobilité des élites. Reconversions et circulation internationale. Iași: Editura Universităţii „Al. I. Cuza”.

Liiceanu, G. (1983). Jurnalul de la Păltiniș [Paltiniș Diary]. București: Cartea Romanească.

Livezeanu, I. (2003). Romania's Cultural Wars: Intellectual Debates about the Recent Past. Working Papers Series of the National Council for Eurasian and East European Research (March 27, 2003).

Macrea Toma, I. (2010). Privilighenția. Instituții literare în comunismul românesc [Privileghentia. Literary institutions under Romanian communism], Cluj-Napoca: Casa Cărții de Știință.

Matei, S. (2004). Boierii minţii. Intelectualii români între grupurile de prestigiu şi piaţa liberă a ideilor [Boyars of the mind. Romanian intellectuals between elite groups and the open market of ideas]. București: Compania.

Mocănescu, A. (2011). Artists and Political Power: The Functioning of the Romanian Artists' Union during the Ceauşescu Era, 1965-1975. In C. Pălășan, M. Stan and C. Vasile (eds.).

Negură, P. (2014). Nici eroi, nici trădători. Scriitorii moldoveni şi puterea sovietică în epoca stalinistă [Neither heros, nor traitors. Moldovian writers and soviet power under Stalinism]. Chişinău: Cartier.

Pălășan, Corina, Stan Marius and Vasile Cristian. 2011. Avatars of Intellectuals Under Communism, History of Communism in Europe, v. 2 / 2011).

Pavel, D. and I. Huiu (2003). „Nu putem reusi decit impreuna”. O istorie analitica a Conventiei Democratice, 1989-2000 [We can win only together. A historical analysis of the Democratic Convention, Iași: Polirom.

Petri, G. (ed.) (2004). Patronage. Personal Networks and the Party-State: everyday Life in the Cultural Sphere in Communist Russia and East Central Europe, Trondheim Studies on East European Cultures \& Societies, No. 13,Trondheim. 
Răduță, M. (2005). «Les Jeunes Loups». Genèse et affirmation d'une génération littéraire dans la Roumanie post-communiste. In M.D. Gheorghiu (ed.): Littérature et pouvoir symbolique. București: Ed. Paralela 45, pp. 268-291.

Runceanu, C. (2008). «Grup de reflecție», grup solidar? Grupul pentru Dialog Social: o elită intelectuală în post-comunism, In M.D. Gheorghiu and M. Lupu Mihăiță (eds.): Mobilitatea elitelor în România secolului al XX-lea [The mobility of Romanian elites in the 19th century]. București: Ed. Paralela 45, pp. 392-421.

Sapiro, G. (1999). La Guerre des écrivains. 1940-1953. Paris: Fayard.

Scott, J. (2000). Social network analysis: a handbook, London: Sage.

Şiulea, C. (2003). Retori, simulacre, impostori. Cultură şi ideologii în România [Rectors, simulacre, impostors. Culture and ideologies in Romania]. București: Compania.

Tănase, S. (2002). Acasă se vorbește în șoaptă [At home we speak only with whispers]. București: Compania.

Tolz, V. (2004). "Cultural Bosses" as Patrons and Clients: the Functioning of the Soviet Creative Unions in the Postwar World. In G. Petri (ed.): Patronage. Personal Networks and the Party-State: everyday Life in the Cultural Sphere in Communist Russia and East Central Europe, Trondheim Studies on East European Cultures \& Societies, nr. 13, Trondheim.

Tomoff, K. (2004). "Most Respected Comrade..." Patrons, Clients, Brokers and Unofficial Networks in the Stalinist Music World. In G. Petri (ed.): Patronage. Personal Networks and the Party-State: everyday Life in the Cultural Sphere in Communist Russia and East Central Europe, Trondheim Studies on East European Cultures \& Societies, nr. 13, Trondheim.

Vasile, C. (2010). Literatura și artele în România comunistă [Literature and arts in communist Romania], vol. I, 1948-1953, București: Humanitas.

Vasile, C. (2011). Politicile culturale comuniste în timpul regimului Gh. Gheorghiu Dej [Communist cultural policies under Gh.Gheorghiu Dej]. București: Humanitas.

Vasile, C. (2014). Viaţa intelectuală şi artistică în primul deceniu al regimului Ceauşescu, 1965-1974 [Intellectual and artistic life in the first decade of the Ceauşescu regime, 1965-1974]. București: Humanitas.

Verdery, Katherine, 1991. National ideology under socialism. Identity and Cultural Politics in Ceaușescu's Romania, Berkeley and Los Angeles, University of California Press.

Wachtel, A. B. (2003). Writers and Society in Eastern Europe, 1989-2000: The End of the Golden Age. East European Politics and Societies, 17(4): 583-621.

Wachtel, A. B. (2006). Remaining Relevant after Communism, University of Chicago Press.

Walker, B. (2004). Kruzsok Culture: The Meaning of Patronage in the Early Soviet Literary World. In G. Petri (ed). Patronage. Personal Networks and the Party-State: everyday Life in the Cultural Sphere in Communist Russia and East Central Europe, Trondheim Studies on East European Cultures \& Societies, nr. 13, Trondheim. 
